\title{
KEMAMPUAN MAHASISWA MEMBACA TEKS ILMIAH PADA PROGRAM STUDI PENDIDIKAN BAHASA INDONESUA FKIP UNTAN PONTIANAK
}

\author{
Endang Susilowati \\ Staf Pengajar Program Studi Bahasa Indonesia FKIP Untan \\ Email: endangsusilowati@gmail.com
}

\begin{abstract}
This study was aimed at obtaining a deep understanding of the students' ability to read scientific texts, the obstacles they face, and how to overcome students' difficulties of the second semester of the Indonesian Language and Literature Education Study Program in 2020 of FKIP Untan Pontianak. The results of the students' ability to read scientific texts are used as teaching policies in an effort to motivate and increase students in reading scientific texts to make them better. The method used in this research was descriptive, a form of quantitative research. The data of this research ere the test results of the ability to read scientific texts regarding literal understanding, interpretation, evaluation, and understanding of appreciation. Sources of data in this study were students of the Indonesian Language and Literature Education Study Program, semester II of 2020, FKIP Untan Pontinak. Data collection tools were objective test questions on reading comprehension and content interpretation. The data analysis used quantitative descriptive techniques. The validity of the data was done by checking the validity of the data and it was proven by the triangulation proposed by Robin and Meleong. The reliability of the ability to read scientific texts was determined by the reliability of the rating results. Based on the research results, it can be concluded that the students' ability to read scientific texts had an average value of 74.46. This study covered 30 students. There were 22 students with good grades above 70. There are 8 students whose grades were below 70 or not good. The obstacles faced by students in reading scientific texts were students who were not accurate in answering questions $26.6 \%$, who did not master the vocabulary of absorption elements $27 \%$, who did not understand the meaning of words based on the context of written sentences 30\%. Students who did not master the meaning of foreign loan words, $23 \%$, were less able to interpret meanings and read evaluatively 27\%. The solutions and suggestions given to overcome these obstacles were as follows: Students are trained to read comprehension critically, to look for difficult vocabulary elements of foreign language absorption, to explain their meaning and use them in the context of other sentences, to assess evaluative reading both in groups and individually. Students also need to take the initiative to learn on their own even though they are not assigned /supervised by lecturers.
\end{abstract}

Keywords: Students’ Ability, Reading, Scientific Text

\begin{abstract}
Abstrak
Penelitian ini bertujuan untuk memperoleh pemahaman yang mendalam kemampuan mahasiswa membaca teks ilmiah, hambatan yang dihadapi, dan cara mengatasi kesulitan mahasiswa pada Prodi Pendidikan Bahasa dan Sastra Indonesia semester II tahun 2020 FKIP Untan Pontianak. Kemudian, hasil nilai kemampuan mahasiswa membaca teks ilmiah dijadikan kebijakan pengajar dalam usaha memotivasi dan peningkatan mahasiswa membaca teks ilmiah agar lebih baik.Metode yang digunakan dalam penelitian ini deskriptif, bentuk penelitian kuantatif. Data penelitian ini adalah hasil tes kemampuan membaca teks ilmiah mengenai pemahaman harfiah (literal), interpretasi, evaluasi, dan pemahaman apresiasi. Sumber data dalam penelitian ini adalah mahasiswa Prodi Pendidikan Bahasa dan Sastra Indonesia semester II tahun 2020 FKIP Untan Pontinak. Alat pengumpul data yaitu soal tes objektif tentang pemahaman bacaan dan interpretasi isi. Teknik analisis data deskriptif kuantitatif. Validitas data dengan teknik pemerikasaan keabsahan data dan dibuktikan dengan trianggulasi yang dikemukakan oleh Robin dan Meleong. Analisis data secara kuantitatif. Reabilitas kemampuan membaca teks ilmiah ditentukan dengan rehabilitas hasil rating. Berdasarkan hasil penelitian dapat disimpulkan hasil kemampuan mahasiswa membaca teks ilmiah nilai rata-rata 74,46. Penelitian ini berjumlah 30 orang. Mahasiswa yang nilainya baik di atas 70 berjumlah 22 orang. Mahasiswa yang nilainya di bawah 70 atau belum baik berjumlah 8 orang. Hambatan yang dihadapi mahasiswa dalam membaca teks ilmiah yaitu mahasiswa yang kurang cermat menjawab soal pertanyaan berjumlah
\end{abstract}




\begin{abstract}
26,6 \%, tidak menguasai kosa kata unsur serapan $27 \%$, kurang memahami arti kata berdasarkan konteks kalimat tertulis $30 \%$. Mahasiswa kurang menguasai arti kata serapan asing $23 \%$, kurang mampu memaknai arti dan membaca secara evaluatif $27 \%$. Solusi dan saran yang diberikan untuk mengatasi hambatan tersebut sebagai berikut. Mahasiswa dilatih untuk membaca pemahaman secara kritis, mencari kosa kata sulit unsur serapan bahasa asing, menjelaskan artinya dan menggunakannya dalam konteks kalimat yang lain, membaca evaluatif baik secara berkelompok maupun individu. Mahasiswa juga perlu berinisiatif belajar sendiri meskipun tidak ditugaskan/diawasi dosen.
\end{abstract}

\title{
Kata Kunci: Kemampuan Mahasiswa, Membaca, Teks Ilmiah
}

\section{PENDAHULUAN}

Membaca merupakan suatu keterampilan berbahasa yang sangat penting peranannya dalam kehidupan. Membaca mempunyai peranan penting dalam melahirkan generasi penerus bangsa yang cerdas, kreatif, dan kritis. Dengan membaca seseorang mendapat pengetahuan dan informasi dari berbagai penjuru dunia. Manusia yang berbudaya dan berpendidikan menjadikan membaca menjadi suatu kebutuhan dalam hidupnya untuk dapat berkomunikasi dengan baik antarsesamanya, begitu pula dalam mmembaca teks ilmiah

Teks ilmiah merupakan suatu tulisan yang membahas berbagai materi dan hasil penelitian yang mampu untuk dijadikan sebuah pembelajaran dan sumber ilmu. Teks ilmiah meliputi teks referensi dan ilmiah popular. Manfaat penting yang didapat seseorang dalam membaca teks ilmiah, yaitu pembaca mendapatkan informasi baru. Pembaca memahami dan mengerti penulisan penulisan berbagai teks ilmiah. Pembaca memperluas pola pikir dan cara pandang tehadap suatu karya dan dapat melatih dan meningkatkan kemampuan membaca.

Permasalahan yang sering dihadapi seseorang dalam membaca di antaranya adalah ketidakmampuan untuk memilih hal yang akan dibacanya, atau tentang cara membaca suatu teks ilmiah. Ketidakmampuan seseorang dalam membaca teks ilmiah dapat dikarenakan faktor fisik atau kondisi tubuh, faktor intelek atau pemikiran dan faktor lingkungan. Berdasarkan pengamatan penulis tidak semua mahasiswa Program Studi Pendidikan Bahasa Indonesia FKIP Untan Pontianak memilkki kemampuan memahami teks bacaan ilmiah dengan baik. Sehubungan dengan itu, peneliti ingin mengetahui kemampuan mahasiswa Reguler A dan PPAPK semester II secara pasti mengenai membaca teks ilmiah dan hambatan yang dihadapi.

Hasil penelitian terdahulu yang relevansi dengan kajian yang akan peneliti lakukan. untuk meyakinkan genuinitas penelitian yang akan dilakukan. Pertama, penelitian yang telah dilakukan oleh Erlina yang berjudul " Peninkatan
Kemampuan Memahami Bacaan Bahasa Arab melalui Penerapan Teknik Pembelajaran SQ4R (Penelitian Tindakan pada Mahasiswa Jurusan Pendidikan Bahasa Arab Fakultas Tarbiyah IAIN Raden Intan Lampung. Temuan penelitian ini berupa peningkatan kemampuan mahasiswa memahami bacaan (Erlina, 2012).

Kedua, penelitian yang telah dilakukan oleh Hangga Aria Adhi Pratama, dkk. Yang berjudul "Peningkatan Keterampilan membaca cepat untuk Menemukan Ide Pokok dengan Menggunakan Strategi Membaca Fleksibel dan Metode Think, Pair, and, Share' dalam Jurnal Bahasa, Volume 4, Nomor 1, 2014. Penelitian ini bertujuan untuk mendeskripsikan proses dan hasil pembelajaran membaca cepat dengan menggunakan strategi membaca fleksibel dan dan metode think, pair, and, share. Pengumpulan data dilakukan dengan observasi partisipan, wawancara, tes, dan catatan lapangan.

Penelitian yang dilakukan oleh Erlina dan Hangga Aria Adhi Pratama dkk. menunjukkan bahwa penggunaan strategi membaca fleksibel dan metode think, pair, and, share tersebut dapat meningkatkan proses pembelajaran membaca cepat. Penelitian yang dilakukan oleh Hangggara berbeda dengan yang peneliti lakukan.

Berdasarkan uraian di atas, maka penulis tertarik untuk mengadakan penelitian serta ingin mengetahui tentang kemampuan mahasiswa membaca teks ilmiah pada Program Studi Pendidikan Bahasa Indonesia FKIP Untan Pontianak.sebagai sebuah panduan pembelajaran mengenai materi membaca, dengan tujuan menjadikan membaca merupakan hal yang perlu diperhatikan terutama dalam membaca teks ilmiah.

Peneliti memahami yang mendalam, mendeskripsikan tentang kemampuan mahasiswa Program Studi Pendidikan Bahasa Indonesia Semester II FKIP Untan Pontianak dalam membaca teks ilmiah. Selain itu, untuk mengetahui tentang hambatan yang dihadapi oleh mahasiswa serta mencari solusi cara mengatasi hambatan yang dihadapi mahasiswa Program Studi Pendidikan Bahasa Indonesia Semester II FKIP Untan Pontianak dalam membaca teks ilmiah? 
Kemampuan adalah suatu dasar seseorang yang dengan sendirinya berkaitan dengan pelaksanaan pekerjaan secara efektif atau sangat berhasil. Kemampuan itu dipengaruhi oleh fktor kondisi fisik, kecerdasan, kekuatan, kecakapan, dan keterampilan (Sinaga dan Hardiati, 2001:34). Jadi kemampuan di sini adalah kesanggupan melakukan sesuatu dalam memahami bacaan teks ilmiah.

Membaca adalah suatu proses yang dilakukan pembaca untuk memperoleh pesan atau informasi dan teks yang dibacanya. Dalam proses tersebut pembaca berusaha merekonstruksi pesan yang ada dalam teks. Pada kegiatan membaca terjadi proses pengolahan informasi masukan yang terdiri atas informasi visual dan informasi nonvisual (Grabe,2009:14).

Teks ilmiah adalah teks yang hanya bisa disampaikan dalam bentuk tulisan saja, sedangkan menurut KBBI, ilmiah artinya bersifat ilmu, secara ilmu pengetahuan; memenuhi syarat (kaidah) ilmu pengetahuan.

Membaca adalah suatu proses yang dilakukan pembaca untuk memperoleh pesan atau informasi dan teks yang dibacanya. Dalam proses tersebut pembaca berusaha merekonstruksi pesan yang ada dalam teks. Pada kegiatan membaca terjadi proses pengolahan informasi masukan yang terdiri atas informasi visual dan informasi nonvisual (Grabe, 2009:14).

Menurut Nurhadi (dalam Somadayo, 2011:1-2) membaca adalah suatu proses yang kompleks dan rumit. Kompleks berarti dalam proses membaca terlibat berbagai factor internal dan factor eksternal pembaca. Faktor internal berupa factor inteligensi, minat, sikap, bakat, motivasi, tujuan membaca, dan sebagainya. Faktor eksternal bisa dalam bentuk sarana membaca, teks bacaan, factor lingkungan, kebiasaan, dan tradisi membaca.

Teks hampir sama dengan wacana, bedanya kalau teks hanya bisa disampaikan dalam bentuk tulisan saja, sedangkan wacana bisa disampaikan dalam bentuk lisan maupun tertulis. Selanjutnya teks ilmiah adalah teks yang hanya bisa disampaikan dalam bentuk tulisan saja, sedangkan menurut KBBI, ilmiah artinya bersifat ilmu, secara ilmu pengetahuan; memenuhi syarat (kaidah) ilmu pengetahuan. Segala sesuatu yang dibuat berdasarkan ilmu pengetahuan dapat disebut bersifat ilmiah seperti metode ilmiah, penelitian ilmiah, karya tulis ilmiah, dan sebagainya.

Tujuan membaca teks ilmiah adalah untuk memperoleh kesuksesan dalam pemahaman penuh terhadap argumen-argumen yang logis, urutan-urutan etoris atau pola-pola teks, pola-pola simbolisnya, nada-nada tambahan yang bersifat emosional dan juga sarana-sarana linguistik yang dipergunakan untuk mencapai tujuan (Tarigan, 2008:36)

Manfaat membaca teks ilmiah sebagai berikut: (1) Memperluas cakrawala ilmu pengetahuan mutakhir di dunia mengenai kualitas dalam penulisan maupun isi dalam karya ilmiah tersebut; (2) Meningkatkan keterampilan pemahaman bacaan dalam engorganisasikan dan menyajikan fakta dan data secara jelas dan sistematis; (3) Dapat mengikuti perkembangan ilmu pengetahuan dan teknologi mutakhir di dunia mengantarkan seseorang menjadi cerdik dan pandai; (4) Dapat memperkaya perbedaan kata, ungkapan, istilah, dan lain-lain yang sangat menunjang keterampilan menyimak, berbicara dan menulis.

Demikian besar manfaat yang dapat dipetik dari kegiatan membaca. Emerson, seorang filosof kenamaan yang mengharapkan setiap orang (termasuk pelajar) dapat membiasakan diri sebagai pembaca yang baik.

Membaca merupakan suatu keterampilan yang kompleks yang melibatkan serangkaian keterampilan yang lebih kecil lainnya. Agar seseorang mampu mencapai suatu tingkat pemahaman, seharusnyalah ia mengalami proses yang cukup panjang.

Dalam membaca teks ilmiah, pembaca tidak hanya dituntut sekadar mengerti dan memahami isi bacaan, tetapi ia juga harus mampu menganalisis atau mengevaluasi dan mengaitkannya dengan pengalaman-pengalaman dan pengetahuan awal yang telah dimilikinya.

Menurut Tanjung dan Ardial (2010:7) makalah adalah karya tulis yang memuat pemikiran tentang suatu masalah topik tertentu yang ditulis secara sistematis dan runtut dengan disertai analisis yang logis dan objektif. Makalah adalah karya tulis ilmiah yang menyajikan suatu masalah yang pembahasannya berdasarkan data di lapangan yang bersifat empiris-objektif. Makalah biasanya disajikan dalam sebuah seminar atau dipresentasikan di kelas (tugas perkuliahan).

Dari sifatnya makalah dapat dibedakan menjadi 3 jenis, berikut: (1) Makalah Deduktif adalah makalah yang di dasarkan pada kajian teoritis yang relevan dengan permasalahan yang dibahas; (2) Makalah Induktif adalah makalah yang ditulis berdasrkan data empiris yang berisfat objektif berdasarkan apa yang diperoleh dari lapangan namun tetap relevan dengan pembahasan; (3) Makalah Campuran adalah makalah yang di tulis berdasarkan kajian teoritis dan data empiris, artinya makalah ini ada pengabungan dari makalah deduktif dan makalah induktif.

Menurut McLaughlin dan Allen dalam Farida Rahim, mengemukakan mengenai 
prinsip-prinsip membaca sebagai berikut: (1) Pemahaman merupakan proses konstruktivis sosial; (2) Keseimbangan kemahiraksaraan adalah kerangka kerja kurikulum yang membantu perkembangan pemahaman; (3) Guru membaca yang profesional (unggul) mempengaruhi belajar siswa; (4) Pembaca yang baik memegang peranan yang strategis dan berperan aktif dalam proses membaca; (5) Membaca hendaknya terjadi dalam konteks yang bermakna; (6) Siswa menemukan manfaat membaca yang berasal dari berbagai teks pada berbagai tingkatan kelas; (7) Perkembangan kosakata dan pembelajaran mempengaruhi pemahaman membaca; (8) Pengikutsertaan adalah suatu faktor kunci pada proses pemahaman; (9) Strategi dan keterampilan membaca bisa diajarkan; (10) Asesmen yang dinamis menginformasikan pembelajaran membaca pemahaman (McLaughlin dan Allen dalam Farida Rahim, 2008: 3-4).

Dalam memahami bahan bacaan, langkahlangkah yang perlu dilakukan dalam membaca, berikut: (1) menentukan tujuan membaca; (2) preview artinya membaca selayang pandang; (3) membaca secara keseluruhan isi bacaan dengan cermat sehingga kita dapat menemukan ide pokok yang tertuang dalam setiap paragrafnya; (4) mengemukakan kembali isi bacaan dengan menggunakan kalimat dan kata- kata sendiri (Suyatmi, 2000:45).

Adanya kemampuan membaca pemahaman yang tinggi diharapkan dapat menangkap ide pokok yang terdapat dalam bacaan, menemukan hubungan de pokok dengan ide pokok yang lain secara keseluruhan. Selanjutnya dapat menghubungkan yang dipaham bahan bacaan tersebut dengan ide diluar bahan bacaan.

Penilaian kemampuan dalam membaca menurut Anderson dijabarkan dalam beberapa teknik dalam menilai kemampuan membaca siswa atau mahasiswa sebagai berikut. Multiplechoice techniques, maching techniques , ordering task, dichotomous items, editing test, alternative integrated approach, the cloze elide test, short answer test, the free-recall test, the summary test, the gapped summary, informaston transfer teqniques (Alderson, 2000:202).

Brown menjelaskan beberapa penilaian pada kemampuan membaca yaitu multiplechoice, short-answer question, sentence completion, notes/summary/diagram/flow chart/table completion (Brown,2008:205).

Lin dan Gronlund menuliskan daftar kecakapan membaca yang biasa dilakukan untuk mengukur kemampuan siswa dengan beberapa identifikasi berikut: (1) mengidentifikasi makna yang diberikan; (2) mengidentifikasi makna kata ketika digunakan dalam konteks; mengidentifikasi kata yang disampaikan teks secara terperinci; (4) mengidentifikasi pokok pikiran yang disampaikan secara tidak langsung di dalam sebuah teks; (5) mengidentifikasi hubungan (sebab akibat, waktu) di dalam suatu teks; dan (6) mengidentifikasi kemampuan dalam menarik kesimpulan dari suatu teks (Linn dan Gronlund, 1995: 209)

Berdasarkan penjelasan di atas peneliti menetapkan penilaian kemampuan memahami bacaan teks ilmiah yang dijadikan acuan meliputi empat indicator yang terkait dengan tingkatan pemahaman bacaan. Dalam hal ini pemahaman harfiah (literal), pemahaman interpretative, pemahaman evaluative, dan pemahaman apresiatif. Kemudian ditetapkan skor, penjumlahan skor yang diperoleh kemampuan membaca mahasiswa. Selanjutnya menjumlahkan seluruh skor yang diperoleh dan menjumlahkan skor dan menetapkan nilai kemampuan mahasiswa memahami teks bacaan ilmiah.

\section{METODE PENELITIAN}

Metode yang digunakan dalam penelitian ini adalah metode deskriptif. Metode ini digunakan untuk menggambarkan atau memaparkan objek penelitian tentang kemampuan mahasiswa membaca teks ilmiah berdasarkan data yang diperoleh berdasarkan fakta yang tampak sesuai dengan kenyataan yang ada.

Bentuk penelitian ini adalah penelitian kuantitatif, karena bermaksud untuk memahami fenomena, mendeskripsikan dalam bentuk berupa nilai angka- angka (Emzir,2012: 57). Dalam hal ini mendeskripsikan tentang kemampuan mahasiswa semester II tahun 2020 membaca teks ilmiah pada Program Studi Pendidikan Bahasa Indonesia FKIP Untan Pontianak.

Populasi penelitian ini adalah mahasiswa semester II Prodi Pendidikan Bahasa Indonesia, FKIP Untan Pontianak tahun ajaran 2019/2020 berjumlah 90 orang. Mahasiswa regular kelas A berjumlah 31 orang, dan B 31 orang. Mahasiswa PPAPK berjumlah 28 orang. Sampel penelitian ini digunakan sampel acak yaitu antara 20-30\% dari jumlah populasi. Berdasarkan pengambilan sampel tersebut, maka yang diambil $30 \%$ yaitu berjumlah 30 orang (Arikunto, 2010:13).

Teknik pengumpul data dalam penelitian ini digunakan tes. Alat pengumpul data yaitu berupa soal pilihan ganda atau tes objektif yang harus dijawab oleh mahasiswa sampel regular kelas A dan B serts kelas PPAPK, semester II Prodi Pendidikan Bahasa Indonesia, KIP Untan Pontianak tahun ajaran 2019/2020.

Uji keabsahan data dalam penelitian ini 
dilakukan untuk memastikan kebenaran dan reliabilitas data yang didapatkan. Pengujian ini dilakukan melalui tiga tahapan berikut. Ketekunan pengamat dilakukan oleh penelitidalam pengambilan data di lapangan yaitu bertujuan agar tidak terjadi kesalahan dan data yang didapat akurat dan lengkap. Diskusi teman sejawat dilakukan oleh peneliti untuk memperoleh informasi tambahan dan dan masukan yang berupa teori maupun referensi belajar lainnya.

rianggulasi adalah teknik pemeriksaan keabsahan data yang memanfaatkan sesuatu yang lain di luar data itu untuk keperluan pengecekan atau sebagai pembanding terhadap data itu (Moleong, 2011:330). Berhubungan dengan itu untuk pengecekan data harus dipenuhi syarat!) kredibilitas, 2) kebergantungan,

3) keteralihan, 4) kepastian.

Untuk mengetahui kemampuan mahasiswa dalam membaca teks ilmiah aspek yang dinilai dan diuji yaitu menjawab soal pertanyaan dalam memahami isi bacaan dan interpretasi bacaan.

Kemudian ditetapkan skor, penjumlahan skor yang diperoleh kemampuan membaca mahasiswa. Selanjutnya menjumlahkan seluruh skor yang diperoleh dan dan menetapkan nilai kemampuan mahasiswa memahami teks bacaan ilmiah

Tabel 1. Kriterian Kemampuan Mahasiswa Membaca Teks Ilmiah

\begin{tabular}{lll}
\hline Nilai & Kualitas & Huruf/Nilai \\
\hline $85-100$ & Amat Baik & A \\
\hline $70-84$ & Baik & B \\
\hline $60-69$ & Cukup & C \\
\hline $50-59$ & Kurang & D \\
\hline$<49$ & Sangat & E \\
& Kurang & \\
\hline
\end{tabular}

Teknik analisis data dalam penelitian adalah deskriptif kuantitatif. Teknik analisis data dilakukan dengan cara berikut. (1) Pengumpulan data penelitian: mengadakan tes kemampuan mahasiswa memahami isi bacaan teks ilmiah yang meliputi indikator: tes pemahaman harfiah (literal) dan pemahaman interpretative mahasiswa Prodi Bahasa Indonesia Semester II tahun ajaran 2019/2020; (2) Analisis data hasil tes: kemampuan mahasiswa dalam memahami isi bacaan teks ilmiah dengan statistika deskriptif yang digunakan meliputi mean(rerata), distribusi frekuensi, dan persentase; (3) Mendiskusikan: membimbing mahasiswa untuk meningkatkan memahami bacaan; (4) Mencari solusi hambatan yang dihadapi; (5) Kesimpulan akhir: kemudian disimpulkan dengan deskripsi kata-kata mengenai hasil penelitian kemampuan mahasiswa membaca teks ilmiah regular A dan kelas PPAPK semester II Prodi Pendidikan Bahasa Indonesia, FKIP Untan Pontianak tahun ajaran $2019 / 2020$.

Berdasarkan hasil analisis data tentang penelitian yang berjudul, "Kemampuan mahasiswa semester II Membaca Teks Ilmiah pada Program Studi Pendidikan Bahasa Indonesia FKIP Untan Pontianak", dengan tujuan untuk memberikan gambaran yang jelas tentang permasalahan kemampuan mahasiswa semester II membaca teks ilmiah. Selain itu, untuk mengetahui kesulitan yang dihadapi oleh mahasiswa dalam membaca teks ilmiah, kemudian dicari solusinya untuk mengatasi permasalahan tersebut agar kedepannya kemampuan mahasiswa dalam membaca teks ilmiah lebih baik dan meningkat. Untuk lebih jelasnya kemampuan mahasiswwa dalam membaca teks ilmiah dapat dikemukakan berikut.

Tabel 2. Nilai Kemampuan mahasiswa semester II Membaca Teks Ilmiah pada Program Studi Pendidikan Bahasa Indonesia FKIP Untan Pontianak

\begin{tabular}{ccccc}
\hline Nomor & $\begin{array}{c}\text { Kode } \\
\text { Mahasiswa }\end{array}$ & $\begin{array}{c}\text { Nilai Tes } \\
\text { Bacaan 1 }\end{array}$ & $\begin{array}{c}\text { Nilai Tes } \\
\text { Bacaan 2 }\end{array}$ & Jumlah Nilai \\
\hline 1 & A & 50 & 50 & 100 \\
\hline 2 & B & 40 & 36 & 76 \\
\hline 3 & C & 40 & 36 & 76 \\
\hline 4 & D & 40 & 36 & 76 \\
\hline 5 & E & 30 & 36 & 66 \\
\hline 6 & F & 40 & 36 & 76 \\
\hline 7 & G & 40 & 36 & 76 \\
\hline 8 & H & 40 & 36 & 69 \\
\hline 9 & $I$ & 40 & 29 & 66 \\
\hline 10 & J & 40 & 36 & 79 \\
\hline 11 & K & 30 & 36 & \\
\hline 12 & $\mathrm{~L}$ & 43 & 36 & \\
\hline
\end{tabular}




\begin{tabular}{ccccc}
\hline 13 & M & 30 & 36 & 66 \\
\hline 14 & $\mathrm{~N}$ & 40 & 36 & 76 \\
\hline 15 & $\mathrm{O}$ & 40 & 29 & 69 \\
\hline 16 & $\mathrm{P}$ & 40 & 36 & 76 \\
\hline 17 & $\mathrm{O}$ & 40 & 29 & 69 \\
\hline 18 & $\mathrm{R}$ & 40 & 36 & 76 \\
\hline 19 & $\mathrm{~S}$ & 30 & 36 & 66 \\
\hline 20 & $\mathrm{~T}$ & 30 & 43 & 73 \\
\hline 21 & $\mathrm{U}$ & 30 & 43 & 73 \\
\hline 22 & $\mathrm{~F}$ & 30 & 43 & 73 \\
\hline 23 & $\mathrm{~W}$ & 30 & 43 & 76 \\
\hline 24 & $\mathrm{X}$ & 40 & 36 & 69 \\
\hline 25 & $\mathrm{Y}$ & 40 & 29 & 76 \\
\hline 26 & $\mathrm{Z}$ & 40 & 36 & 76 \\
\hline 27 & $\mathrm{~A} 1$ & 40 & 36 & 76 \\
\hline 28 & $\mathrm{~B} 1$ & 40 & 36 & 83 \\
\hline 29 & $\mathrm{C} 1$ & 40 & 36 & $\mathbf{2 2 3 4}$ \\
\hline 30 & $\mathrm{D} 1$ & 40 & $\mathbf{1 1 0 1}$ & $\mathbf{7 4 , 4 6}$ \\
\hline Jumlah & & $\mathbf{1 1 3 3}$ & $\mathbf{3 6 , 7 0}$ & \\
\hline Rerata & & $\mathbf{3 7 , 7 6}$ & & \\
\hline
\end{tabular}

Berdasarkan hasil penelitian tentang "Kemampuan mahasiswa semester II Membaca Teks Ilmiah pada Program Studi Pendidikan Bahasa Indonesia FKIP Untan Pontianak", dapat disimpulkan sebagai berikut. Hasil kemampuan mahasiswa membaca teks ilmiah nilai rata-rata mencapai 74,46. Penelitian berjumlah 30 orang mahasiswa. Mahasiswa yang nilainya sudah baik di atas 70 dalam membaca teks ilmiah sejumlah
22 orang. Mahasiswa yang nilainya di bawah 70 atau belum baik berjumlah 8 orang. Berdasarkan hasil analisis data tentang penelitian yang berjudul, "Kemampuan mahasiswa semester II Membaca Teks Ilmiah pada Program Studi Pendidikan Bahasa Indonesia FKIP Untan Pontianak", hambatan yang dihadapi mahasiswa dapat dilihat pada tabel berikut.

Tabel 3. Hambatan yang Dihadapi Mahasiswa Semester II Membaca Teks Ilmiah pada Program Studi Pendidikan Bahasa Indonesia FKIP Untan Pontianak

\section{No. Hambatan yang Dihadapi Mahasiswa}

Mahasiswa

1. Mahasiswa kurang cermat dalam memahami teks bacaan ilmiah

$8 \quad 26,6$

kadang-kadang tergesa-gesa dalam menjawab soal pertanyaan.

\begin{tabular}{llcc}
\hline 2. & $\begin{array}{l}\text { Mahasiswa tidak menguasai kosa kata dari unsur serapan yang } \\
\text { cukup. }\end{array}$ & $\mathbf{8}$ & $\mathbf{2 7}$ \\
\hline 3. & $\begin{array}{l}\text { Mahasiswa kurang memahami arti kata berdasarkan } \\
\text { konteks kalimat yang tertulis. }\end{array}$ & $\mathbf{1 0}$ & $\mathbf{3 0}$ \\
\hline 4. & $\begin{array}{l}\text { Mahasiswa kurang menguasai arti kata unsur serapan yang berasal } \\
\text { dari Bahasa asing. }\end{array}$ & $\mathbf{7}$ & $\mathbf{2 3}$ \\
\hline 5. & $\begin{array}{l}\text { Mahasiswa kurang mampu memaknai arti kata yang terkandung di } \\
\text { dalamnya dan secara evaluatif }\end{array}$ & $\mathbf{8}$ & $\mathbf{2 7}$ \\
\hline
\end{tabular}

Berdasarkan tabel di atas dapat dikemukakan hambatan yang dihadapi mahasiswa dalam membaca teks ilmiah meliputi berikut: (1) Mahasiswa yang kurang cermat memahami teks bacaan ilmiah, kadang tergesagesa dalam menjawab soal pertanyaan berjumlah 26,6 \%; (2) Mahasiswa yang tidak menguasai kosa kata unsur serapan $27 \%$; (3) Mahasiswa yang kurang memahami arti kata berdasarkan konteks kalimat yang tertulis $30 \%$; (4) Mahasiswa yang kurang menguasai arti kata unsur serapan bahasa asing $23 \%$; (5) Mahasiswa yang kurang mampu memaknai arti atau maksud makna kata yang terkandung di dalamnya dan secara evaluatif $27 \%$. 


\section{SIMPULAN DAN SARAN Simpulan}

Berdasarkan analisis data hasil penelitian mengenai " Kemampuan mahasiswa semester II Membaca Teks Ilmiah pada Program Studi Pendidikan Bahasa Indonesia FKIP Untan Pontianak", dapat disimpulkan sebagai berikut: Hasil kemampuan mahasiswa membaca teks ilmiah nilai rata-rata mencapai 74,46 . Penelitian berjumlah 30 orang mahasiswa. Mahasiswa yang nilainya sudah baik di atas 70 dalam membaca teks ilmiah sejumlah 22 orang. Mahasiswa yang nilainya di bawah 70 atau belum baik berjumlah 8 orang. Hambatan yang dihadapi mahasiswa dalam membaca teks ilmiah meliputi berikut. Mahasiswa yang kurang cermat dalam memahami teks bacaan ilmiah, kadang tergesagesa dalam menjawab soal pertanyaan $26,6 \%$. Mahasiswa yang tidak menguasai kosa kata unsur serapan $27 \%$. Mahasiswa yang kurang memahami arti kata berdasarkan konteks kalimat yang tertulis $30 \%$. Mahasiswa yang kurang menguasai arti kata unsur serapan bahasa asing $23 \%$. Mahasiswa yang kurang mampu memaknai arti kata yang terkandung di dalamnya $27 \%$.

\section{Saran}

Solusi yang dapat dilakukan untuk mengatasi hambatan mahasiswa semester II dalam membaca teks ilmiah sebagai berikut. Mahasiswa dilatih membaca pemahaman secara kritis, baik secara kelompok maupun individu. Mahasiswa dilatih membaca pemahaman mencari kosa kata yang sulit mengenai unsur serapan dari bahasa asing, kemudian disuruh menjelaskan artinya. Mahasiswa dilatih membaca pemahaman berdasarkan konteks kalimat yang tertulis dan mengartikan maknanya, kemudian ditugaskan menggunakannya dalam kalimat yang lain dan menjelaskan artinya, serta latihan membaca evaluatif baik secara kelompok maupun individu. Saran Saran yang dapat diberikan berkaitan dengan hasil penelitian sebagai berikut. Mahasiswa perlu diberikan latihan lebih banyak lagi dalam praktik keterampilan membaca yang berkaitan dengan membaca pemahaman teks ilmiah secara kritis. Dalam hai ini, mencari kosa kata yang sulit unsur serapan asing, latihan memaknai makna kata yang terkandung di dalamnya, membaca evaluatif baik secara kelompok maupun individu dalam kelas. Selain itu, meskipun mahasiswa tidak diberikan tugas membaca pemahaman teks ilmiah secara kritis, mahasiswa juga perlu berinisiatif belajar sendiri meskipun tidak ditugaskan/diawasi dosen.

\section{DAFTAR PUSTAKA}

Alderson, J. Charles. 2000. Assessing Reading New York: Chambridge University.

Arikunto, Suharsimi. 2010.Penelitian Tindakan Kelas, Yogyakarta: Aditya Media. Brown, H. Dauglas. Prinsip Pembelajaran dan Pengajaran Bahasa Terjemahan Noor Cholis dan Yus Avianto Pareanom . Jakarta: Kedubes A.S. Dwiloka, Bambang. 2005. Teknik Menulis Karya Ilmiah. Penerbit Rineka Cipta.

Emzir, 2012. Metodologi Penelitian Kuantitatif dan Kualitayif. Jakarta: PT Rajagrafindo Persada

Erlina,.2012. Peningkatan Kemampuan Memahami Bacaan Bahasa Arab melalui Penerapan Teknik Pembelajaran SQ4R (Penelitian Tindakan pada Mahasiswa Jurusan Pendidikan Bahasa Arab Fakultas Tarbiyah IAIN Raden Intan Lampung, Disertasi Universitas Negeri Jakarta 2012.

Farkhan, M. 2006. Penulisan Karya Ilmiah. Jakarta: Penerbit Cella.

Grabe, William. 2009. Reading in Second Language: Moving from Theory to Practice. New York: Chambridge University Press.

Hariwijaya, M. 2008. Pedoman Penulisan Ilmiah Proposal dan Skripsi. Tugu Publisher.

Linn, Robert L. and Norman E. Gronlund, Measurement and Assessment in Teaching. New York: MerrilPrentice Hall. 1995.

Moleong, Lexy. 2017. Metode Penelitian Kualitatif. Bandung: Remaja Rosda Karya.

Nurgiyantoro, Burhan. 2010.Penilaian Pembelajaran Bahasa. Yogyakarta: BPFEYogyakarta.

Nurhadi.205. Bagaimana Cara Meningkatkan Kemampuan Membaca?. Bandung: Sinar Baru Algesindo.

Pratama, Hangga Aria Adhi, dkk."Peningkatan Keterampilan Membaca Cepat untuk Menemukan Ide Pokok dengan Menggunakan Strategi Membaca Fleksibel dan Metode Think, Pair, and Share". Dalam Jurnal Bahasa. Volume 4, N0.1 2014, Diakses 17 September 2019.

Sinaga, Anggiat M. dan Sri Hardiati, 2001. Pembelajaran Sumber Daya Manusia. Jakarta: Lembaga Administrasi Negara Republik Indonesia.

Somadayo, Samsu, 2011. Strategi dan Teknik Pembelajaran Membaca. Yogyakarta: Graha Ilmu.

Tarigan, Henry Guntur. 2008. Membaca Sebagai Suatu Keterampilan Berbahasa. Bandung: Agkasa. http://www.gurupendidikan.co.id/6pengertian-tujuan-dan-manfaat-karyailmiah- enurut-para-ahli 